\title{
Stingray Injuries
}

\author{
FINDLAY E. RUSSELL, M.D.
}

$I^{1}$ NJURIES inflicted by stingrays are common in several areas of the coastal waters of North America (1-4). Approximately 750 people a year along our coasts are stung by these elasmobranchs. The largest number of stings are reported from southern California, the Gulf of California, the Gulf of Mexico, and the south Atlantic coast (5).

Of 1,097 stingray injuries reported over a 5 year period in the United States $(5,6), 232$ were seen by a physician at some time during the course of the recovery of the victim. Sixtytwo patients were hospitalized; the majority of these required surgical closure of their wounds or treatment for secondary infection, or both. At least 10 of the 62 victims were hospitalized for treatment for overexuberant first aid care. Only eight patients were hospitalized for the treatment of the systemic effects produced by the venom. There were two fatalities.

Considerable care should be exercised when wading in shallow waters known to be inhabited by stingrays. Stingray injuries usually occur when the unwary victim treads upon the fish while wading in the ocean surf or mud flats of a bay, slough, or river. The fish often buries itself in the sandy or muddy bottom and may remain motionless until stepped upon. The pressure of the foot on the dorsum of the fish provokes him to thrust his tail upward and forward, driving his sting into the foot or leg of the victim. As the sting enters the flesh,

Dr. Russell is director of the laboratory of neuro. logical research of the College of Medical Evangelists and Los Angeles County Hospital. Basic data in the report were obtained from studies supported by the Office of Naval Research, Dazian Foundation for Medical Research, and the Public Health Service. the integumentary sheath surrounding the spine is ruptured and the venom escapes into the victim's tissues. In withdrawing the spine, the integumentary sheath may be torn free and remain in the wound.

Unlike the injuries inflicted by many venomous animals, wounds produced by the stingray may be large and severely lacerated, requiring extensive debridement and surgical closure. A sting no wider than $5 \mathrm{~mm}$. may produce a wound $3.5 \mathrm{~cm}$. long (6), and larger stings may produce wounds 7 inches long ( 7$)$. Occasionally, the sting itself may be broken off in the wound.

The sting, or caudal spine, is a bilaterally serrated dentinal structure located on the dorsal surface of the animal's tail. The sharp serrations are curved cephalically and as such are responsible for the lacerating effects as the sting is withdrawn from the victim's flesh. The location, size, and number of stings vary with the species, habitat, and age of the fish. The round stingray, now designated as Urolophus halleri, which is implicated in the majority of injuries along the southern California coast, has one or more stings of 1.6 to $5.9 \mathrm{~cm}$. long (8). The giant stingray of Australia, Bathytoshia, may possess a caudal spine of $42.0 \mathrm{~cm}$. long (9).

The greatest portion of venom is contained within the two ventrolateral grooves of the sting. In the untraumatized state, the sting is incased in an integumentary sheath. The anatomic relationships of the sheath and sting have been described elsewhere (10-12).

\section{Chemical and Zootoxicological Properties}

The toxic fractions of the venom are soluble proteins of average molecular weight. They 
are extremely labile and rapidly inactivated by heating. Ten amino acids have been identified in the venom. The total nitrogen, carbohydrate, and protein for $100 \mathrm{mg}$. of the venom has been calculated as $3.1 \mathrm{mg}$., $3.3 \mathrm{mg}$., and $24.9 \mathrm{mg}$. respectively. The intravenous $\mathrm{LD}_{50}$ of the lyophilized venom is estimated at $28.0 \mathrm{mg}$. $/ \mathrm{kg}$. of body weight (13).

In addition to the local effects (12), the venom produces changes in the cardiovascular, respiratory, nervous, and urinary systems $(5,14,15)$. Low concentrations of the toxin give rise to simple, transient peripheral vasodilatation or vasoconstriction. The most consistent change in the electrocardiographic pattern of cats when small amounts of the venom are injected is bradycardia with an increase in the PR interval, giving a first degree atrioventricular block with but slight change in the blood pressure. Reversal of the small dose effect occurs within 30 seconds following the end of the injection $(14,15)$.

Larger amounts produce constriction of the arteries and veins as well as the arterioles, and second or third degree atrioventricular block. The second degree block is usually followed by sinus arrest. In addition to the PR interval change, ST, $\mathrm{T}$ wave changes indicative of ischemia and, in some animals, true muscle injury are seen $(15,16)$. Concomitant with these changes is a fall in systemic arterial pressure. It is apparent that the venom affects the normal pacemaker of the heart. Most of the cardiovascular changes revert to normal within 24 hours (5).

Lethal amounts of the venom cause marked vasoconstriction and cardiac standstill of varying durations. All degrees of atrioventricular block as well as defects in intraventricular conduction occur, and if death is not immediate, the rhythm of the normal pacemaker is replaced by one elaborated outside the sino-atrial node. The blood pressure falls rapidly, and the animal dies in complete cardiovascular collapse $(5,14,15)$. Concomitant with these changes are alterations in the respiratory and central nervous systems $(5,13)$. The venom has no effect on neuromuscular conduction (17). Postmortem examination of animals which have survived for 4 days following a lethal dose of the venom show few gross changes. However, pulmonary edema, engorgement of the liver sinusoids, and vascular congestion with tubular epithelial necrosis in the loop of Henle are seen $(13)$.

\section{Diagnosis}

Persons stung by stingrays report having received a sharp, painful stab, usually in the foot or leg, while swimming or wading in an area where these animals are present. The pain is usually described as intense or excruciating; it increases in severity during the first $90 \mathrm{~min}$ utes following the stinging if treatment is not instituted. The pain is out of proportion to that which might be produced by a nonvenomous fish or by stepping upon a broken bottle or bivalve. "Stingings" by broken bottles are a common occurrence along certain of our coasts, according to the lifeguard services.

Examination reveals either a puncture or a lacerating wound, usually the latter, jagged, bleeding freely, and often contaminated with parts of the stingray's integumentary sheath. The edges of the wound may be discolored, though the discoloration is not usually marked immediately following the injury. However, within 2 hours the discoloration may extend several centimeters from the wound. Subsequent necrosis of this area is not uncommon in untreated cases.

Edema is a constant finding following stingings by these animals. The edema is not as severe as one sees following a rattlesnake bite, but it may persist for several weeks in the untreated case. Syncope, weakness, nausea, nervousness, and sweating are common complaints. Vomiting, diarrhea, tremors, general-

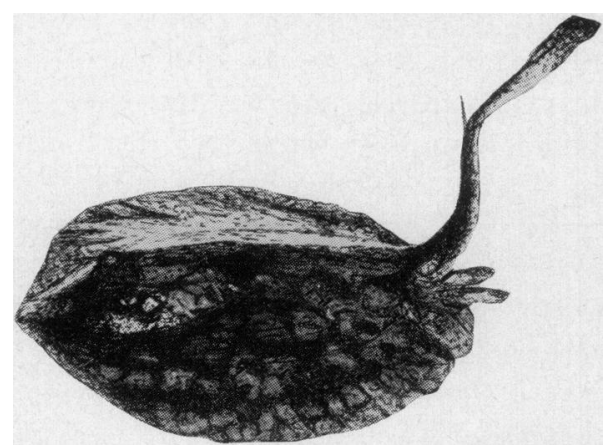

The round stingray Urolophus halleri 


\section{An Early Case History}

An early stingray victim was Captain John Smith. Walter Russell, "Gentleman, doctor of physicke," who accompanied Smith as he explored Chesapeake Bay in June 1608, described the encounter in chapter 5 , "The Accidents that hapned in the Discovery of the Bay of Chisapeack" of The Third Booke of The Proceedings and Accidents of the English Colony in Virginia.

... Having finished this discovery (though our victuall was neere spent) he intended to see his imprisonment-acquaintances upon the river of Rapahanock, by many called Toppahanock, but our bote by reason of the ebbe, chansing to grownd upon a many shoules lying in the entrances, we spyed many fishes lurking in the reedes: our Captaine sporting himselfe by nayling them to the grownd with his sword, set us all a fishing in that manner: thus we tooke more in owne houre then we could eate in a day.
But it chansed our Captaine taking a fish from his sword (not knowing her condition) being much of the fashion of a Thornback. but a long tayle like a ryding rodde, whereon the middest is a most poysoned sting, of two or three inches long, bearded like a saw on each side, which she strucke into the wrest of his arme neere an inch and a halfe: no bloud nor wound was seene, but a little blew spot, but the torment was instantly so extreme, that in foure houres had so swolen his hand, arme and shoulder, we all with much sorrow concluded his funerall, and prepared his grave in an Island by, as himselfe directed: yet it pleased God by a precious oyle Doctor Russell at the first applyed to it when he sounded it with probe, (ere night) his tormenting paine was so well asswaged that he eate of the fish to his supper, which gave no lesse joy and content to us then ease to himselfe. For which we called the island Stingray Isle after the name of the fish. ... ized cramps, inguinal or axillary pain, and respiratory distress are less frequently reported. Arrhythmias, paresthesias, and convulsions may occur. True paralysis is extremely rare, if it occurs at all. The "paralyses" seen by the author following severe stingings were contractures, probably initiated as flexion reflexes stimulated by the intense pain. These contractures were relieved with meperidine hydrochloride.

\section{Treatment}

The standard procedure for treatment of stingray injuries is well established (5). As the chief complaint is immediate, intense, localized pain, the treatment will be most successful if the victim initiates it. Injuries to an extremity should be irrigated with the salt water at hand, since much of the venom can be washed from the wound by this step. An attempt should be made to remove the integumentary sheath if it can be seen in the wound. If a properly qualified person is available, he may apply a constriction band directly above the wound site. The extremity should then be submerged in hot water at as high a temperature as the patient can tolerate without injury for 30 to 90 minutes. The addition of sodium chloride or magnesium sulfate to the hot water is optional.

In many areas of the United States the lifeguard services provide the first aid care just described, and the victim usually arrives at the hospital emergency room or physician's office in little acute pain and with few, if any, other complaints. The wound should then be further examined for evidence of the integumentary sheath, debrided, sutured if necessary, and the appropriate antitetanus agents administered. While infections of these wounds are rare in properly treated cases, some physicians routinely give antibiotics. Elevation of the injured extremity is advised.

Irrigation is contraindicated if the sting has entered the abdominal or thoracic cavity, and the patient should be hospitalized. In such cases, the patient should be explored surgically 
for the presence of the ray's integumentary sheath (5). Exploration is indicated if the sting has pierced the peritoneum or pleura. Such exploration may require considerable time, since the sheath may be torn into several small pieces. The venom is rapidly absorbed in the peritoneal cavity, and should the offending ray be a large one, the prognosis is poor in the presence of an unremoved sheath. It is also possible for the toxin to be expressed from the venom apparatus without the sheath being left in the wound.

In severe stings, which provoke systemic symptoms, the victim should also be hospitalized. The primary shock often seen immediately following these injuries usually responds to simple supportive measures. If secondary shock develops as a result of the direct effects of the venom, the physician must direct his efforts toward maintaining cardiovascular and respiratory tone. Oxygen should always be given. Meperidine hydrochloride has been found' to be effective in controlling the pain $(5,6)$. Experiments with mice have shown that the drug does not alter the $\mathrm{LD}_{50}$ of the venom (5).

\section{Summary}

Injuries inflicted by stingrays are common in several areas of the coastal waters of North America. Approximately 750 people a year along our coasts are stung by these elasmobranchs. About 20 percent of those injured are seen by a physician some time during the course of their recovery; 6 percent are hospitalized.

In the untraumatized state, the sting is encased in an integumentary sheath. The greatest portion of the venom is contained within the ventrolateral grooves of the sting.

The toxic fractions of the venom are soluble proteins of average molecular weight which are extremely labile and rapidly inactivated by heating. While the venom produces changes in the respiratory and central nervous systems, its principal action is on the cardiovascular system.

The chief complaint following a sting by one of these animals is severe pain. Syncope, weakness, nausea, nervousness, and sweating are common complaints. Vomiting, diarrhea, tremors, generalized cramps, inguinal or axillary pain, and respiratory distress are less frequently reported. Arrhythmias, parasthesias, and convulsions may occur.

Treatment is aimed toward alleviating the pain, preventing complications that may be evoked by the venom, and preventing secondary infections. The following therapy is suggested. Irrigate the wound thoroughly, removing the animal's integumentary sheath if present. Apply a constriction band directly above the wound site until hot water can be prepared. Soak affected part in hot water for 30 to 90 minutes. Debride and close wound as necessary. Administer appropriate antitetanus agent and antibiotic. Keep affected part elevated.

\section{REFERENCES}

(1) Gudger, E. W.: Is sting ray's sting poisonous? Historical résumé showing development of our knowledge that it is poisonous. Bull. Hist. Med. 14: 467-504, November 1943.

(2) Halstead, B. W., and Bunker, N. C.: Stingray attacks and their treatment. Am. J. Trop. Med. 2 : 115-128, January 1953.

(8) Russell, F. E.: The stingray. Engineer. \& Sc. 17 : 15-18, December 1953.

(4) Halstead, B. W.: Dangerous marine animals. Cambridge, Md., Cornell Maritime Press, 1959, pp. 1-146.

(5) Russell, F. E., Panos, T. C., Kang, L. W., Warner, W. M., and Colket, T. C.: Studies of the mechanism of death from stingray venom. A report of two fatal cases. Am. J. M. Sc. 235: 566-584, May 1958.

(6) Russell, F. E.: Stingray injuries: A review and discussion of their treatment. Am. J. M. Sc. 226 : 611-622, December 1953.

(7) Cleland, J. B. : Injuries and diseases in Australia attributable to animals. M. J. Australia 2: 313-320, Oct. 3, 1942.

(8) Russell, F. E.: Multiple caudal spines in the round stingray, Urobatis halleri. California Fish \& Game 41 : 213-217, July 1955.

(9) Gudger, E. W.: Bathytoshia, the giant stingaree of Australia. The largest of the sting-ray tribe in the seven seas. Australian Museum Mag. 205-210, April-June 1937.

(10) Ocampo, R. R., Halstead, B. W., and Modglin, F. R.: The microscopic anatomy of the caudal appendage of the spotted. eagleray, Aëtobatus marinari (Euphrasen) with special reference to the venom apparatus. Anat. Rec. 115: 87-99, January 1953. 
(11) Halstead, B. W., Ocampo, R. R., and Modglin, F. R.: A study of the comparative anatomy of the venom apparatus of certain North American stringrays. J. Morphol. 97 : 1-21, July 1955.

(12) Russell, F. E., and Lewis, R. D.: Evaluation of the current status of therapy for stingray injuries. In Venoms, edited by E. E. Buckley and N. Porges. Washington, D.C., American Association for the Advancement of Science, 1956, pp. 43-53.

(13) Russell, F. E., Fairchild, M. D., and Michaelson, J.: Some properties of the venom of the stingray. M. Arts \& Sc. 12: 78-86, Second Quarter, 1958.

(14) Russell, F. E., and van Harreveld, A.: Cardiovascular effects of the venom of the round stingray, Urobatis halleri. Arch. internat. physiol. 62 : 322-333, September 1954.

(15) Russell, F. E., Barritt, W. C., and Fairchild, M. D.: Electrocardiographic patterns evoked by venom of the stingray. Proc. Soc. Exper. Biol. \& Med. 96 : 634-635, December 1957.

(16) Russell, F. E., and van Harreveld, A.: Cardiovascular effects of the venom of the round stingray Urobatis halleri. In Venoms, edited by E. E. Buckley and N. Porges. Washington, D.C., American Association for the Advancement of Science, 1956, pp. 33-41.

(17) Russell, F. E., and Long, T. E. : Effects of venoms on neuromuscular transmission. Second International Symposium on Myasthenia Gravis. In press. films

\section{The Innocent Party}

16-mm. film, color, sound, 17 minutes, 1959.

Audience: Students, parents, educators, civic groups, health workers, and the general public.

This film, depicting the problems of teenagers with venereal diseases, documents simply, forthrightly, and in good taste the nature, recognition, cure, and control of syphilis.

Suitable for mixed audiences, it was shown before release to groups of parents, teachers, educators, Catholic and Protestant clergy, public health officials, and teenagers.

The film was produced by the Kansas State Board of Health in cooperation with the Public Health Service. It may be borrowed from the film library of the Communicable
Disease Center, Atlanta, Ga., by high schools, colleges, youth organizations, and civic groups, as well as health departments, and will be offered for sale by an independent contractor.

Information concerning loan or purchase may be obtained from Dr. William J. Brown, Chief, Venereal Disease Branch, Communicable Disease Center, Public Health Service, 50 Seventh Street NE., Atlanta 23, Ga.

\section{George Washington's River}

16-mm. film, color, sound, original music, 28 minutes, cleared for television, 1959.

Audience: Sanitarians, persons inferested in conserving natural resources, and the general public.

From a depiction of George Washington's time when he built his home at Mount Vernon "on the finest river in the world," this new water pollution film takes the audience to present-day scenes of the polluted Potomac. The ugliness of the pollution emanating from the metropolitan area is contrasted with the fresh, clear headwaters of the Potomac. Scenes include national shrines, cherry blossom time at the Tidal Basin, and a long-forgotten bathing beach in Washington.

The film shows how cities and industries can manage their wastes and restore the streams for fishing, boating, swimming, and domestic and industrial requirements.

Film libraries or agencies considering the purchase of a print can obtain a preview copy from the Division of Water Pollution Control, Public Health Service, Washington 25, D.C. Distribution for public showings will be made from film service libraries only.

Prints can be purchased, at $\$ 95.42$ each postpaid, from the Motion Picture Service, Office of Information, U.S. Department of Agriculture, Washington 25, D.C. 


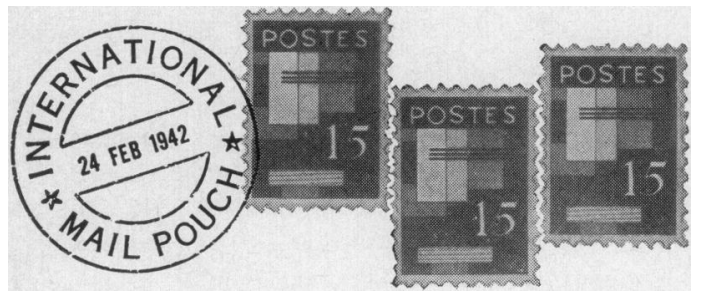

\section{Medical Center}

A national medical center for Korea opened October 2, 1958, in Seoul. The largest modern medical facility in the Far East, the center has 465 beds and was financed with $\$ 2.4$ million from UNKRA funds and $\$ 2$ million contributed by Norway, Sweden, and Denmark. For its first 5 years of operation the center will have approximately 80 Scandinavian staff members, supported by an annual $\$ 1.5$ million contribution from the three countries. The entire facility will be turned over to Korea in 1963.

-Alfred S. Lazarus, chief, Health and Sanitation Division, U.S. Operations Mission, Korea.

\section{Ojos de Agua}

The Ministries of Agriculture, Education, and Health joined forces in a new rural development at Ojos de Agua, a small community in southeastern El Salvador. An earth-cement brick-making machine, used here for the first time, manufactures bricks for a new school, houses, and water supply units. The water units consist of laundries, showers, drinking fountains, watering troughs for animals, and food-washing vats. The community is building approved latrines for each of $\mathbf{4 2 0}$ houses.

-Lamar A. Byers and W. C. James, chief and acting chief, Health and Sanitation Division, U.S. Operations Mission, El Salvador.

\section{The Well Diggers}

Twelve thousand new or rehabilitated wells will be put into operation in East Pakistan this year. The wells will provide a safe source of water. Villagers customarily use open tanks for bathing and laundering as well as for drinking water.
The government of East Pakistan has contracted with 220 small contractors, each with 2 or 3 crews of 4-man gangs, to dig new tube wells or put clogged wells back into service. Most of the wells are less than 200 feet deep. In the Dacca area, 2,294 out of the scheduled 3,370 wells were finished in 30 days.

The village water supply project required nearly 350 miles of $1 \frac{1}{2}$-inch galvanized iron pipe, 10,000 hand pumps, 1,000 deep-well hand pumps, and quantities of pipe fittings, strainers, well points, spare parts for the clogged wells, and hand tools.

-Anthony Donovan, M.D., chief public health adviser physician, U.S. Operations Mission, Pakistan.

\section{Tuberculosis in Israel}

The number of tuberculosis cases in Israel has dropped so that 750 beds are sufficient for hospitalized tuberculous patients. Other tuberculosis facilities have been converted into general wards, homes for the aged, and mental hospitals.

Ten years ago, when 1,000 immigrants were arriving daily, 12 out of 1,000 had signs of the disease.

Through efforts of the Ministry of Health, trade unions' sick funds, and philanthropic organizations, the number of beds for tuberculosis patients increased from 348 in 1948 to 2,200 by 1953 .

Malben, a philanthropic organization, took on the task of rehabilitating discharged patients, totaling 7,000 in 1958 alone.

\section{Malaria in Southeast Asia}

To coordinate malaria eradication, 40 officers and technicians from Laos and Thailand met at a border conference at Nongkhai, Thailand, February 2-6, 1959. In 1959 eradication efforts will serve 14 million Thai and 700,000 Lao, an increase of 2 million persons in Thailand and 300,00 in Laos.

In large areas of Thailand the malaria eradication program is almost complete, and less than half of the operational areas require spraying this year. Laos will continue spraying in all operational areas and start surveillance activities in areas of 175,000 population.

-Melvin E. Griffith, acting chief, public health division, U.S. Operations Mission, Thailand. 